\title{
KONWERGENCJA GOSPODARCZA W WYBRANYCH KRAJACH OECD W ŚWIETLE TESTÓW KOINTEGRACJI NIELINIOWEJ
}

Z a ry s treści. W artykule podjęto próbę weryfikacji hipotezy konwergencji gospodarczej w odniesieniu do 8 krajów OECD: Australii, Francji, Japonii, Kanady, Stanów Zjednoczonych, Szwecji, Wielkiej Brytanii i Włoch, na podstawie danych rocznych z okresu po II wojnie światowej. W badaniu wykorzystano analizę kointegracji szeregów czasowych umożliwiającą weryfikację hipotezy konwergencji deterministycznej i stochastycznej. W analizie tej zastosowano testy dopuszczające asymetrię i nieproporcjonalność prędkości dostosowania gospodarek do ich stanów równowagi, opisywane za pomocąodpowiednio - logistycznych i wykładniczych funkcji przejścia w dwu- i trzyreżimowych modelach klasy STAR, tj. testy logistycznej i wykładniczej kointegracji wygładzonego przejścia. Osłabienie założenia o liniowości w analizie kointegracji pozwoliło wskazać znacznie więcej przypadków kointegracji oraz istotnie wzmocniło wnioskowanie na temat konwergencji gospodarczej. Procesy dostosowawcze do badanych zależności długookresowych wydają się charakteryzować oboma typami nieliniowości, tj. zarówno asymetrią, jak i nieproporcjonalnością. Otrzymane wyniki stoją w zgodzie z ekonometrycznymi implikacjami neoklasycznego modelu wzrostu Solowa-Swana.

Słow a kluczowe: $\beta$-konwergencja, kointegracja nieliniowa, modele STAR, neoklasyczne modele wzrostu.

\section{WPROWADZENIE}

Chociaż hipoteza konwergencji znana jest ekonomistom od czasów Davida Hume'a, a w teorii wzrostu gospodarczego jest dyskutowana już od lat pięćdziesiątych, to intensyfikacja badań teoretycznych i empirycznych w tej dziedzinie obserwowana jest dopiero od początku lat dziewięćdziesiątych. Badania te służą 
odpowiedzi na pytania istotne nie tylko z poznawczego punktu widzenia - wyniki tych dociekań mają również istotne implikacje dla prowadzenia polityki ekonomicznej. Celem artykułu jest próba weryfikacji hipotezy konwergencji gospodarczej w odniesieniu do 8 krajów OECD: Australii, Francji, Japonii, Kanady, Stanów Zjednoczonych, Szwecji, Wielkiej Brytanii i Włoch, na podstawie danych rocznych z okresu po II wojnie światowej. W badaniu wykorzystuje się analizę kointegracji, umożliwiającą weryfikację hipotezy o tzw. konwergencji deterministycznej i stochastycznej. W analizie tej osłabia się założenie o liniowości procesów dostosowawczych do położenia równowagi długookresowej, przyjmując - zgodnie z implikacjami neoklasycznych modeli wzrostu - iż prędkość dostosowania może być wyższa dla dużych odchyleń od steady state, a mała lub zerowa dla odchyleń niewielkich, a ponadto może zmieniać się w zależności od tego, czy gospodarka zbiega do położenia równowagi z dołu czy z góry. W związku z tym w weryfikacji hipotezy konwergencji proponuje się testy kointegracji wygładzonego przejścia przy przyjęciu logistycznej lub wykładniczej funkcji transformacji. Testy te mają wyższą moc od klasycznych testów kointegracji, jeśli procesy dostosowawcze rzeczywiści są nieproporcjonalne bądź niesymetryczne - patrz Bruzda (2007).

W części drugiej artykułu dyskutuje się definicje konwergencji gospodarczej oraz wskazuje podstawowe metody weryfikacji hipotezy konwergencji. W części trzeciej prezentuje się bardziej szczegółowo podejście metodologiczne wykorzystywane w części czwartej, poświeconej w całości wynikom badania empirycznego. Najważniejsze wnioski zawiera krótkie Podsumowanie.

\section{KONWERGENCJA GOSPODARCZA - PODSTAWY TEORETYCZNE}

Pojęcie konwergencji gospodarczej jest rozumiane różnorako. Po pierwsze, należy rozróżnić konwergencję realną i nominalną, gdzie ta pierwsza oznacza konwergencję obiektywnie istniejącą lub obserwowana, druga zaś ma charakter normatywny lub będący realizowanym celem (patrz np. Malaga, 2007). Konwergencję nominalną należy traktować jako kategorię polityczną w ujęciu traktatu z Maastrich, której celem jest stworzenie i sprawne funkcjonowanie Unii Monetarnej i Gospodarczej w ramach Unii Europejskiej. Ten rodzaj konwergencji opiera się na czterech kryteriach: stabilności cen, stabilności finansów publicznych, stabilności kursu walutowego i stabilności długoterminowej stopy procentowej.

$\mathrm{Z}$ kolei konwergencja realna jest zwykle rozumiana dwojako (patrz Islam, 2003, a w literaturze polskiej Malaga, 2004, s. 7-9; Nowak, 2005). W pierwszym znaczeniu oznacza ona zbieżność gospodarki lub grupy gospodarek do stanu równowagi, którego charakterystyk dostarcza teoria ekonomii. Ów stan równowagi 
może zmieniać się w czasie na skutek zmian określających go egzogenicznych parametrów, pozostając jednak w każdym momencie atraktorem rzeczywistości gospodarczej. W rozumieniu tym konwergencja gospodarcza ma więc ścisłe związki z teorią ekonomii. W znaczeniu drugim konwergencja to wyrównywanie się poziomu bogactwa narodów. W myśl hipotezy konwergencji potencjał wzrostu krajów biedniejszych przewyższa odpowiedni potencjał krajów bogatszych, dzięki czemu te pierwsze doganiają (ang. catch-up) te drugie. Wśród teoretycznych wyjaśnień tej hipotezy wskazuje się najczęściej transfer technologii, tj. podnoszony już przez Davida Hume'a argument, że naśladownictwo jest dla gospodarek znacznie mniej kosztowne niż innowacyjność oraz implikacje pewnych matematycznych modeli wzrostu (zwłaszcza modeli wzrostu egzogenicznego).

W myśl neoklasycznego modelu wzrostu, zakładającego malejące korzyści skali względem odtwarzalnych czynników wzrostu, rozwój gospodarek wykazuje zbieżność do stacjonarnego stanu równowagi. Stan ów nie zależy od początkowego poziomu dochodu per capita. Jednakże im wyższy jest poziom początkowy dochodu per capita, tym niższa jest stopa wzrostu gospodarczego. Nie oznacza to jednak, że kraje bogatsze zawsze rozwijają się wolniej niż kraje biedniejsze. W ujęciu przekrojowym stopa wzrostu jest bowiem skorelowana nie z poziomem dochodu per capita, ale z dystansem, jaki dzieli gospodarkę od jej stanu równowagi długookresowej. Ten natomiast zależny jest od czynników egzogenicznych, takich jak stopa oszczędności czy stopa wzrostu liczby ludności. Wyrównywanie się poziomów dochodu per capita będzie więc następować jedynie przy tych samych wartościach egzogenicznych parametrów.

Wśród innych wyjaśnień hipotezy konwergencji można wskazać pogląd Olsona (1982), w myśl którego w bogatych gospodarkach występują tendencje do powstawania przeciwnych rynkowi grup interesów, które sprawiają że system gospodarczy staje się coraz mniej wydajny $\mathrm{i}$ - w efekcie - ma miejsce spowolnienie wzrostu. Jako jeden z przykładów ilustrujących swoją argumentację Olson podaje szybki rozwój powojenny krajów, które przegrały wojnę (np. Niemiec i Japonii po II wojnie światowej). Wojna rozbiła bowiem spowalniające wzrost grupy interesów w tych pierwszych krajach, ale nie w krajach zwycięskich.

Wśród operacyjnych (podlegających testowaniu) definicji konwergencji należy wskazać klasyczne już definicje $\sigma$-konwergencji oznaczającej zmniejszanie się dyspersji dochodów per capita w badanej grupie gospodarek, oraz $\beta$-konwergencji postulującej, iż kraje o niższym początkowym poziomie dochodu per capita wykazują wyższe tempo wzrostu niż kraje bogatsze ${ }^{1}$. Dowodzi się,

${ }^{1}$ Rozróżnienie pomiędzy $\sigma$ - i $\beta$-konwergencją zostało zaproponowane przez X. X. Sala-i-Martina w jego rozprawie doktorskiej z 1990 roku: On Growth and States, Harvard University por. też Sala-i-Martin (1996a). 
że występowanie $\beta$-konwergencji jest warunkiem koniecznym występowania konwergencji typu $\sigma^{2}$. Aby wzmocnić wnioskowanie na temat konwergencji typu $\beta$ na podstawie stwierdzonego występowania $\sigma$-konwergencji, Boyle i McCarty (1999) wprowadzają pojęcie $\gamma$-konwergencji, przez którą rozumieją zmniejszanie się współczynnika konkordancji dla dochodów per capita w badanej grupie gospodarek. Wówczas przy braku $\sigma$-konwergencji niewystępowanie także konwergencji typu $\gamma$ jest dodatkową przesłanką na rzecz odrzucenia hipotezy o konwergencji typu $\beta$.

W podejściu $\beta$ rozróżnia się dalej $\beta$-konwergencję absolutną, która pojawia się, gdy wszystkie gospodarki dążą do tego samego stanu stacjonarnego, tj. tego samego poziomu zamożności wyrażonego poziomem dochodu per capita, oraz $\beta$-konwergencję warunkową, w myśl której gospodarki dążą do właściwego sobie steady state zależnego od parametrów strukturalnych, takich jak stopa oszczędności czy stopa wzrostu liczby ludności.

Najczęstszy sposób testowania $\beta$-konwergencji polega na szacowaniu regresji wzrostu (ang. growth regression, Barro regression) postaci:

gdzie:

$$
g_{i, T}=\alpha+\beta \ln Y_{i, 0}+\mathbf{X}_{i, T} \boldsymbol{\delta}+\varepsilon_{i, T},
$$

$Y_{i, T}$ - poziom dochodu per capita dla $i$-tego kraju w momencie $T$, $g_{i, T}=\ln \left(\frac{Y_{i, T}}{Y_{i, 0}}\right)$ - stopa wzrostu,

$\mathbf{X}_{i, T}$ - macierz obserwacji na zmiennych definiujących stan równowagi długookresowej.

Istotna ujemna wartość parametru $\beta$ w regresji (1) pozwala odrzucić hipotezę o braku $\beta$-konwergencji warunkowej. Usunięcie macierzy $\mathbf{X}_{i, T} \mathrm{z}$ równania (1) pozwala natomiast zweryfikować występowanie $\beta$-konwergencji absolutnej. Przy ustalonym $T$ równanie (1) jest regresją przekrojową. Przy takim podejściu do badania konwergencji traci się informacje o zmienności gospodarek w czasie oraz pomija indywidualne nieobserwowane cechy gospodarek. Rozwiązanie stanowi tu zastosowanie danych panelowych, które pozwalają na zwiększenie liczby stopni swobody i uwzględnienie efektów indywidualnych - patrz Ciołek (2003).

Innym sposobem weryfikacji hipotezy o $\beta$-konwergencji jest zastosowanie analizy integracji i kointegracji. Bernard i Durlauf(1995) zaproponowali alternatywną definicję konwergencji, w myśl której między krajami $i$ oraz $j$ występuje konwergencja gospodarcza, jeśli długookresowe prognozy poziomu dochodu per capita $\mathrm{w}$ tych krajach są sobie równe dla ustalonego momentu $T$, tj.:

2 Formalny dowód zawiera praca Furceri (2005), choć na fakt ten zwracano uwagę już znacznie wcześniej - patrz m.in. Sala-i-Martin (1996b); Boyle, McCarty (1999). 


$$
\lim _{k \rightarrow \infty} E\left(\ln Y_{i, T+k}-\ln Y_{j, T+k} \mid I_{T}\right)=0 .
$$

Implikacją ekonometryczną tak rozumianej konwergencji jest występowanie kointegracji między logarytmami dochodu per capita $\mathrm{z}$ wektorem kointegrującym postaci [1, -1]. Li i Pappel (1999) określają konwergencję weryfikowaną na podstawie analizy integracji i kointegracji jako konwergencję szeregów czasowych (ang. time series convergence). Idąc dalej, wyróżniają oni tzw. konwergencję Bernarda-Durlaufa, która pojawia się, gdy proces różnic dochodów (ang. output differential) jest procesem stacjonarnym o średniej 0 , konwergencję deterministyczną występującą w przypadku deterministycznej kointegracji między logarytmami dochodu per capita, oraz konwergencję stochastyczną obserwowana, gdy między logarytmami dochodu per capita występuje kointegracja stochastyczna ${ }^{3}$. Warto zwrócić uwagę, że w przypadku testowania konwergencji deterministycznej lub konwergencji Bernarda-Durlaufa zakłada się, że analizowane gospodarki znajdują się blisko ich steady states, a odchylenia od ich położeń równowagi mają charakter tymczasowy. Zwracają na ten fakt uwagę Bernard i Durlauf (1996) twierdząc, iż testy konwergencji szeregów czasowych mają zastosowanie wówczas, gdy momenty z próby dobrze aproksymują graniczne rozkłady dochodu per capita.

W pracach Mathunjwa, Temple (2006) oraz Christopoulos, León-Ledesma (2007) dyskutuje się implikacje neoklasycznego modelu wzrostu Solowa-Swana ${ }^{4}$ dla dynamiki procesu dochodzenia do długookresowego położenia równowagi. Najważniejszymi wnioskami z tej dyskusji są następujące dwie obserwacje:

1) prędkość dochodzenia do położenia równowagi długookresowej zależy od odległości od tego położenia - im większa odległość, tym wyższa stopa wzrostu;

2) prędkość dochodzenia do steady state jest większa przy zbieganiu z dołu niż z góry.

Z kolei implikacje ekonometryczne powyższych obserwacji są następujące: prędkość dochodzenia do położenia równowagi może być zarówno nieproporcjonalna (większa dla dużych odchyleń i mała lub niewystępująca w ogóle dla małych), jak i niesymetryczna (większa dla odchyleń ujemnych). Sugeruje to możliwość wykorzystania w opisie procesów dostosowawczych nieproporcjonalnych i niesymetrycznych procesów autoregresyjnych kawałkami liniowych (ang. piecewise linear) ${ }^{5}$ ze zmienną przejścia $\mathrm{w}$ postaci opóźnionych poziomów

3 Por. też Attfield (2003).

4 Por. Solow (1956); Swan (1956).

5 Termin piecewise linear processes tłumaczony jest również jako procesy przedziałami liniowe lub procesy segmentowe o segmentach liniowych. 
odchyleń od położenia równowagi (tzw. błędów równowagi), przy czym w wielkościach zagregowanych wygładzone przejścia między reżimami wydają się lepiej uzasadnione niż przejścia gwałtowne. $Z$ tych powodów w dalszej części pracy prezentuje się i wykorzystuje w badaniu empirycznym testy kointegracji wobec alternatyw STAR (ang. smooth transition autoregressive models) - autoregresyjnych procesów wygładzonego przejścia - z wykładniczą (dostosowanie nieproporcjonalne) i logistyczną (dostosowanie niesymetryczne) funkcją przejścia. Testy te charakteryzują się wyższą mocą niż tradycyjne testy kointegracji liniowej w przypadku, gdy dostosowanie do położenia równowagi rzeczywiście jest procesem nieliniowym ESTAR (wykładniczym procesem STAR, ang. exponential STAR)) lub LSTAR (logistycznym procesem STAR, ang. logistic STAR). Opis błędów równowagi za pomocą modeli ESTAR pozwala uwzględnić fakt występowania wyższej prędkości dostosowania dla większych odchyleń od steady state i niższej lub zerowej dla odchyleń małych, podczas gdy modele LSTAR są pomocne w opisywaniu dynamiki asymetrycznej, oznaczającej w analizowanym kontekście wyższą prędkość dostosowani przy zbieganiu do położenia równowagi z dołu niż z góry.

\section{TESTY KOINTEGRACJI STR}

Testy kointegracji wygładzonego przejścia STR (ang. smooth transition cointegration tests) zostały zasugerowane w pracach Kapetanios, Shin, Snell (2006) i Bruzda (2007). Testy te są bardziej uniwersalne od testów kointegracji progowej ze względu na to, iż obejmują one kointegrację progową jako przypadek graniczny. Ponadto wydaje się, że w wielkościach zagregowanych gwałtowne przejścia między reżimami, występujące przy założeniu progowego charakteru dynamiki dostosowań, są mniej prawdopodobne niż przejścia wygładzone, przyjmowane w przypadku kointegracji STR.

W testowaniu kointegracji STR wykorzystuje się dwa podejścia: aproksymację funkcji przejścia szeregiem Taylora niskiego rzędu oraz przeszukiwanie w zbiorze dopuszczalnych wartości parametrów funkcji przejścia. W przypadku pierwszego podejścia rozważenie wykładniczej bądź logistycznej funkcji przejścia ze zmienną przejścia w postaci opóźnionych o 1 poziomów błędów równowagi prowadzi do następujących równań testowych:

$$
\begin{aligned}
& \Delta u_{t}=\alpha_{1} u_{t-1}+\alpha_{2} u_{t-1}^{2}+\varepsilon_{t}, \\
& \Delta u_{t}=\alpha_{1} u_{t-1}+\alpha_{2} u_{t-1}^{2}+\alpha_{3} u_{t-1}^{3}+\varepsilon_{t}, \\
& \Delta u_{t}=\alpha_{1} u_{t-1}+\alpha_{2} u_{t-1}^{2}+\alpha_{3} u_{t-1}^{3}+\alpha_{4} u_{t-1}^{4}+\varepsilon_{t},
\end{aligned}
$$


gdzie $u_{t}$ jest procesem dostosowawczym. Wówczas test hipotezy o braku kointegracji z liniowym procesem dostosowawczym wobec ogólnej alternatywy polega na testowaniu łącznej nieistotności parametrów równań (3)-(5) z wykorzystaniem statystyk $F$ postaci:

$$
F=\frac{\left(S S R_{0}-S S R_{1}\right) / q}{S S R_{1} /(n-q)}
$$

gdzie $S S R_{0}=\sum_{t=1}^{n} \Delta u_{t}^{2}, S S R_{1}$ jest sumą kwadratów reszt odpowiedniego równania testowego, zas $q$ jest liczbą restrykcji. W przypadku występowania autokorelacji reszt w równaniach (3)-(5) stosuje się standardowe rozszerzenie równań analogicznie jak w przypadku rozszerzonego testu Dickeya-Fullera.

W pracy Bruzda (2007) zaproponowano procedurę testowania sekwencyjnego, pozwalającą na rozróżnienie przypadków kointegracji wykładniczej wygładzonego przejścia (ESTR), logistycznej wygładzonego przejścia (LSTR) i kointegracji liniowej, analogiczną do procedury rozstrzygania pomiędzy procesami AR, ESTAR i LSTAR, zaproponowanej przez Teräsvirtę (1994). W procedurze w pracy Bruzda (2007) testy $F$ uzupełnia się testami istotności ostatnich parametrów równań (3)-(5). Wówczas przy założeniu występowania kointegracji, istotność $\alpha_{4}$ W równaniu (5) lub $\alpha_{2}$ w równaniu (3) sugeruje występowanie kointegracji LSTR, natomiast istotność $\alpha_{3}$ w równaniu (4) może być interpretowana jako symptom kointegracji ESTR. Dodatkowo, znaki parametrów $\alpha_{4}$ w równaniu (5) i $\alpha_{2}$ w równaniu (3) informują, który z reżimów (dodatnie czy ujemne odchylenia od położenia równowagi) charakteryzuje się wyższą prędkością dostosowania. Mianowicie, jeśli wspomniany parametr $\alpha_{4}$ jest ujemny, to badany proces szybciej powraca do średniej w reżimie ujemnym, tj. w przypadku, gdy gospodarka zbiega do steady state $\mathrm{z}$ dołu. Podobnie jest, gdy parametr $\alpha_{2} \mathrm{~W}$ równaniu (3) przyjmuje wartość dodatnią ${ }^{6}$.

Wśród testów opartych na przeszukiwaniu zbioru dopuszczalnych wartości parametrów funkcji przejścia szczególną rolę odgrywają testy inf $t$. W teście logistycznej kointegracji STR wykorzystuje się równanie testowe postaci:

$$
\Delta u_{t}=\rho u_{t-1}\left(1-\frac{b}{1+e^{-\gamma u_{t-1}}}\right)+\varepsilon_{t}, 0<b<1, \gamma \neq 0,
$$

które stanowi podstawę dla wyznaczenia statystyki „inf” definiowanej następująco:

$$
\inf _{b, \gamma} t=\inf _{(b, \gamma) \in \mathrm{B} \times \Gamma} \hat{t}_{\rho=0}(b, \gamma) .
$$

6 Patrz na ten temat Bruzda (2007), s. 219. 
Statystyka ta przyjmuje najmniejszą wartość spośród statystyk $t$ wyznaczonych dla dopuszczalnych wartości parametrów $b$ i $\gamma$. Jako zbiór B przyjmuje się zbiór równoodległych punktów pomiędzy wartościami 0 i 1 (w badaniu przyjęto $\mathrm{B}=\{0,01,0,02, \ldots, 0,99\})$, zaś zbiór $\Gamma$ proponuje się zdefiniować $\mathrm{w}$ postaci $\Gamma$ $=\{-20,-19,9, \ldots,-0,1,0,1, \ldots, 19,9,20\}$, co pozwala badać łącznie przypadki wyższej persystencji zarówno $\mathrm{w}$ reżimie dodatnim, jak i w reżimie ujemnym? ${ }^{7}$. W praktyce statystyka (8) wyliczana jest na podstawie równania przeskalowanego postaci:

$$
\Delta u_{t}=\rho u_{t-1}\left[1-\frac{b}{1+e^{-\gamma\left(\frac{u_{t-1}}{s f}\right)}}\right]+\varepsilon_{t},
$$

gdzie $s f=\sqrt{\frac{\sum_{t=1}^{n} u_{t}^{2}}{n}}$ jest tzw. czynnikiem skalującym, a we wnioskowaniu wykorzystuje się jej rozkład bootstrapowy. Z kolei w teście „inf” kointegracji ESTR wykorzystuje się równanie, które w wersji przeskalowanej ma postać:

$$
\Delta u_{t}=\rho u_{t-1}\left[1-e^{-\gamma\left(\frac{\left.u_{t-1}\right)^{2}}{2}\right]}\right]+\varepsilon_{t}, \gamma>0 .
$$

Statystykę ,inf” definiuje się wówczas następująco:

$$
\inf _{\gamma} t=\inf _{\gamma \in \Gamma} \hat{t}_{\rho=0}(\gamma)
$$

a za zbiór $\Gamma$ jest zbiorem pewnych wartości dodatnich $-\mathrm{w}$ badaniu przyjęto $\Gamma=\{0,005,0,01, \ldots, 4.995,5\}^{8}$.

\section{WYNIKI BADANIA EMPIRYCZNEGO}

W badaniu empirycznym wykorzystano dane roczne dotyczące wolumenu PKB per capita z okresu 1946-2007 dla 8 krajów OECD, takich jak: Australia, Francja, Japonia, Kanada, Szwecja, USA i Wielka Brytania. Dane te zaczerpnięto ze strony internetowej A. Maddisona9 ${ }^{9}$. Celem analizy było zbadanie występowania konwergencji deterministycznej i stochastycznej przy osłabieniu założenia

7 Badania symulacyjne (patrz Bruzda, 2007) dowodzą, że przewaga testów kointegracji LSTR nad testami kointegracji liniowej występuje dla większych wartości parametru $\gamma$ (1 i więcej w przypadku statystyki w jej wersji przeskalowanej), natomiast wartości $\gamma$ bliskie 20 wystarczająco dobrze aproksymuja graniczny przypadek kointegracji progowej.

8 W przypadku kointegracji ESTR przewaga testów nieliniowych nad podejściem tradycyjnym pojawia się dla małych wartości parametru $\gamma$ (zwykle poniżej 1 dla statystyk w wersji przeskalowanej).

9 Patrz http://www.ggdc.net/maddison. Dane te są w cenach stałych z roku 1990 dostosowanych ze względu na parytet siły nabywczej pieniądza. 
o liniowości procesów odchyleń od położenia równowagi. Wykorzystano w tym celu testy kointegracji liniowej Engle'a-Grangera oraz testy $F, t$ i „inf” kointegracji LSTR i ESTR z poziomem błędu równowagi jako zmienną przejścia. W pierwszym kroku wykonano testy integracji logarytmów PKB per capita ${ }^{10}$. Testy te pozwalają traktować analizowane procesy jako zintegrowane rzędu 1. Następnie testowano kointegrację między logarytmami wyjściowych procesów dla wszystkich możliwych par gospodarek, tj. przeprowadzono każdy z testów 28 razy $^{11}$. Wyniki zebrano w poniższych tabelach. Istotne statystyki wyróżniono thustym drukiem. W tabeli 1. zawarto wyniki badania występowania kointegracji deterministycznej (statystyka $t_{\mu}$ ) i stochastycznej (statystyka $t_{\tau}$ ) z użyciem testu liniowej kointegracji Engle'a-Grangera. Wyniki te wskazują na występowanie zaledwie 4 przypadków kointegracji deterministycznej i 4 stochastycznej.

Tabela 1. Wyniki testu liniowej kointegracji Engle'a-Grangera

\begin{tabular}{|c|c|c|c|c|c|}
\hline Kraje & $t_{\mu}$ (rozsz.) & $t_{\tau}$ (rozsz.) & Kraje & $t_{\mu}$ (rozsz.) & $t_{\tau}$ (rozsz.) \\
\hline Australia - Francja & $-0751(5)$ & $-3239(5)$ & Japonia - Szwecja & $-0757(1)$ & $-1522(1)$ \\
\hline Australia - Japonia & $-1246(5)$ & $-3181(5)$ & Japonia - UK & $-0692(1)$ & $-1572(3)$ \\
\hline Australia - Kanada & $-1264(2)$ & $-2728(5)$ & Japonia - USA & $-0913(1)$ & $-2164(0)$ \\
\hline Australia - Szwecja & $-1584(2)$ & $-3316(5)$ & Japonia - Włochy & $-2740(0)$ & $-4098(0)^{* *}$ \\
\hline Australia - UK & $-3277(0)^{*}$ & $-2759(0)$ & Kanada - Szwecja & $-2215(0)$ & $-2246(0)$ \\
\hline Australia - USA & $-3637(0)^{* *}$ & $-2887(0)$ & Kanada - UK & $-0793(0)$ & $-1236(0)$ \\
\hline Australia - Włochy & $-0771(3)$ & $-3156(5)$ & Kanada - USA & $-1660(0)$ & $-0706(0)$ \\
\hline Francja - Japonia & $-0715(0)$ & $-3648(0)^{*}$ & Kanada - Włochy & $-1659(1)$ & $-2633(1)$ \\
\hline Francja - Kanada & $-3640(1)^{* *}$ & $-3747(1)^{*}$ & Szwecja - UK & $-1635(2)$ & $-1616(2)$ \\
\hline Francja - Szwecja & $-2825(1)$ & $-2955(1)$ & Szwecja - USA & $-2216(0)$ & $-2367(0)$ \\
\hline Francja - UK & $-1691(1)$ & $-1884(1)$ & Szwecja - Włochy & $-0446(1)$ & $-1782(1)$ \\
\hline Francja - USA & $-3456(0)^{* *}$ & $-3569(0)$ & UK - USA & $-2858(0)$ & $-3195(0)$ \\
\hline Francja - Włochy & $-2267(1)$ & $-3391(1)$ & UK - Włochy & $-0025(1)$ & $-4049(1)^{* *}$ \\
\hline Japonia - Kanada & $-1870(1)$ & $-2500(1)$ & USA - Włochy & $-0660(1)$ & $-3904(0)^{*}$ \\
\hline
\end{tabular}

10 Wyniki są dostępne u autorki.

11 Patrz Pesaran (2007) na temat wyższości podejścia polegającego na badaniu wszystkich par procesów nad badaniem kointegracji z krajem benchmarkowym (najczęściej USA). 
Tabela 2. Wyniki testów $F$ i $t$ kointegracji deterministycznej

\begin{tabular}{|c|c|c|c|c|}
\hline Kraje & $F_{4 N E G}$ (rozsz.) & $F_{3 N E G}$ (rozsz.) & $F_{2 N E G}$ (rozsz.) & $t_{N E G}$ \\
\hline Australia - Francja & $3323(1)^{*}$ & $3980(1)^{*}$ & $1241(1)$ & $-2957(1)^{*}$ \\
\hline Australia - Japonia & $1303(5)$ & $1073(5)$ & $0931(5)$ & $-0908(5)$ \\
\hline Australia - Kanada & $1201(1)$ & $1605(1)$ & 2042 (1) & $-1395(1)$ \\
\hline Australia - Szwecja & $1912(4)$ & $1934(4)$ & $2021(4)$ & $-2373(4)$ \\
\hline Australia - UK & $3540(0)^{*}$ & $4803(0)^{\star \star}$ & $5549(0)^{*}$ & $-3597(5)^{\star *}$ \\
\hline Australia - USA & $5503(0)^{* \star \star}$ & $7217(1)^{\star \star \star}$ & $7199(1)^{* *}$ & $-4687(1)^{* \star *}$ \\
\hline Australia - Włochy & $1679(5)$ & $1985(5)$ & $1527(5)$ & $-0612(5)$ \\
\hline Francja - Japonia & $1592(0)$ & $2140(0)$ & $3157(0)$ & $0117(0)$ \\
\hline Francja - Kanada & $6437(0)^{\star * *}$ & $6769(0)^{\star \star *}$ & $9054(0)^{\star \star *}$ & $-3258(0)^{*}$ \\
\hline Francja-Szwecja & 2070 (1) & $2735(1)$ & 4090 (1) & $-2168(1)$ \\
\hline Francja-UK & $1561(1)$ & $1345(1)$ & $1431(1)$ & $-1997(1)$ \\
\hline Francja-USA & $7273(0)^{\star * *}$ & $7646(0)^{* * *}$ & $10207(0)^{\star \star *}$ & $-4774(0)^{* * \star}$ \\
\hline Francja-Włochy & $1763(1)$ & 2391 (1) & $2888(1)$ & $-2606(1)$ \\
\hline Japonia - Kanada & $1245(1)$ & $1503(1)$ & $1725(1)$ & $-2116(1)$ \\
\hline Japonia - Szwecja & $2192(1)$ & $2415(1)$ & 3640 (1) & $0540(1)$ \\
\hline Japonia - UK & $0971(1)$ & $0617(1)$ & $0710(1)$ & $-0661(1)$ \\
\hline Japonia - USA & $0716(1)$ & $0803(1)$ & $0635(1)$ & $-1211(1)$ \\
\hline Japonia - Włochy & $3982(3)^{* *}$ & $4868(3)^{\star \star}$ & $2165(3)$ & $-3298(3)^{\star \star}$ \\
\hline Kanada-Szwecja & $2928(0)$ & $3175(0)$ & $2958(0)$ & $-2219(0)$ \\
\hline Kanada-UK & $2371(1)$ & $3134(1)$ & $0869(1)$ & $-2100(0)$ \\
\hline Kanada - USA & $0913(0)$ & $1195(0)$ & $1721(0)$ & $-1232(0)$ \\
\hline Kanada - Włochy & $0753(1)$ & $1006(1)$ & $1471(1)$ & $-1305(1)$ \\
\hline Szwecja-UK & $2612(5)$ & $3423(5)$ & $1262(5)$ & $-2445(5)$ \\
\hline Szwecja- USA & $2949(0)$ & $3655(0)$ & $2446(0)$ & $-3115(0)^{*}$ \\
\hline Szwecja - Włochy & $1841(1)$ & $2403(1)$ & $3556(1)$ & $0929(1)$ \\
\hline UK - USA & $6085(0)^{\star \star *}$ & $8012(0)^{\star * *}$ & $4016(0)$ & $-4469(0)^{\star \star \star}$ \\
\hline UK - Włochy & $1053(1)$ & $1218(1)$ & $1581(1)$ & $0492(1)$ \\
\hline USA - Włochy & 0968 (1) & $0923(1)$ & $0983(1)$ & $-0633(1)$ \\
\hline
\end{tabular}


Tabela 3. Wyniki testów $F$ i $t$ kointegracji stochastycznej

\begin{tabular}{|c|c|c|c|c|}
\hline Kraje & $F_{4 N E G}$ (rozsz.) & $F_{3 N E G}$ (rozsz.) & $F_{2 N E G}$ (rozsz.) & $t_{N E G}$ \\
\hline Australia - Francja & $3528(5)$ & $4690(5)$ & $5385(5)$ & $-3707(5)^{\star *}$ \\
\hline Australia - Japonia & $3330(5)$ & $4485(5)$ & $5180(5)$ & $-3628(5)^{\star *}$ \\
\hline Australia - Kanada & $2072(5)$ & $2523(5)$ & $3754(5)$ & $-2179(5)$ \\
\hline Australia - Szwecja & $5142(5)^{\star *}$ & $5853(5)^{\star *}$ & $5394(5)$ & $-3498(5)^{*}$ \\
\hline Australia - UK & $3060(0)$ & $3808(0)$ & $4244(0)$ & $-3146(0)$ \\
\hline Australia - USA & 3331 (1) & $4513(1)$ & $5112(1)$ & $-3197(1)$ \\
\hline Australia - Włochy & $3252(5)$ & $4375(5)$ & $5240(5)$ & $-3619(5)^{\star}$ \\
\hline Francja- Japonia & $6198(0)^{* \star *}$ & $5276(0)^{*}$ & $7954(0)^{\star *}$ & $-3652(0)^{*}$ \\
\hline Francja-Kanada & $6484(0)^{\star \star \star}$ & $6924(0)^{\star *}$ & $8965(0)^{\star *}$ & $-3148(0)$ \\
\hline Francja-Szwecja & 2344 (1) & 2850 (1) & 4351 (1) & $-2239(1)$ \\
\hline Francja - UK & $2942(1)$ & 3533 (1) & 3016 (1) & $-3028(1)^{*}$ \\
\hline Francja - USA & $7256(0)^{* \star *}$ & $7409(0)^{* *}$ & $9928(0)^{* *}$ & $-3514(0)^{*}$ \\
\hline Francja - Włochy & $4541(1)^{*}$ & $5506(1)^{*}$ & $6815(1)^{*}$ & $-3659(1)^{*}$ \\
\hline Japonia - Kanada & 1857 (1) & $2512(1)$ & 3131 (1) & $-2762(1)$ \\
\hline Japonia - Szwecja & 2481 (1) & 2621 (1) & $3509(1)$ & -0680 (1) \\
\hline Japonia - UK & $2886(3)$ & $2232(3)$ & $1612(3)$ & $-2241(3)$ \\
\hline Japonia - USA & $3406(0)$ & $4528(0)$ & $2538(0)$ & $-3487(0)^{*}$ \\
\hline Japonia - Włochy & $12967(0)^{\star * *}$ & $16461(0)^{* * *}$ & $18750(0)^{* * *}$ & $-7099(0)^{\star * *}$ \\
\hline Kanada-Szwecja & $1527(0)$ & $1972(0)$ & $2740(0)$ & $-2104(0)$ \\
\hline Kanada-UK & $1829(0)$ & $2327(0)$ & $0807(0)$ & $-1835(0)$ \\
\hline Kanada - USA & 1640 (1) & $1677(1)$ & 2527 (1) & $-0746(1)$ \\
\hline Kanada - Włochy & $1712(1)$ & 2269 (1) & 3431 (1) & -2077 (1) \\
\hline Szwecja-UK & 2793 (5) & 3627 (5) & $1339(5)$ & $-2523(5)$ \\
\hline Szwecja - USA & $3113(0)$ & $3873(0)$ & $2791(0)$ & $-3278(0)$ \\
\hline Szwecja - Włochy & 1254 (1) & $1662(1)$ & $1625(1)$ & $-2253(1)$ \\
\hline UK - USA & $5233(1)^{\star *}$ & $6801(1)^{\star *}$ & $7206(1)^{*}$ & $-3534(1)^{*}$ \\
\hline UK - Włochy & $5427(1)^{\star \star}$ & $7257(1)^{\star *}$ & $9776(1)^{\star *}$ & $-4173(1)^{\star *}$ \\
\hline USA - Włochy & $5457(0)^{* *}$ & $7233(0)^{\star *}$ & $9030(0)^{* *}$ & $-3696(0)^{* *}$ \\
\hline
\end{tabular}


Tabela 4. Wyniki testów „,inf” kointegracji deterministycznej

\begin{tabular}{|c|c|c|c|c|c|}
\hline Kraje & $\begin{array}{c}\text { LSTR } \\
\left(\begin{array}{c}\text { boot. cv przy } \\
\alpha=10 \%)\end{array}\right.\end{array}$ & $\begin{array}{c}\text { ESTR } \\
\text { (boot. cv przy } \\
\alpha=10 \%)\end{array}$ & Kraje & $\begin{array}{c}\text { LSTR } \\
\text { (boot. cv, przy } \\
\alpha=10 \%)\end{array}$ & $\begin{array}{c}\text { ESTR } \\
\text { (boot. cv przy } \\
\alpha=10 \%)\end{array}$ \\
\hline Australia - Francja & $-1,21(-3,30)$ & $-1,20(-2,97)$ & Japonia- Szwecja & $-2,19(-3,26)$ & $-0,83(-3,43)$ \\
\hline Australia - Japonia & $-1,40(-3,31)$ & $-1,57(-3,20)$ & Japonia - UK & $-1,10(-3,14)$ & $-0,81(-3,30)$ \\
\hline Australia - Kanada & $-1,29(-3,05)$ & $-1,26(-2,75)$ & Japonia - USA & $-1,11(-3,21)$ & $-1,21(-3,20)$ \\
\hline Australia - Szwecja & $-1,59(-2,75)$ & $-1,75(-2,90)$ & Japonia - Włochy & $-3,66(-2,95)$ & $-\mathbf{5 , 1 1}(-2,95)$ \\
\hline Australia - UK & $-3,37(-2,88)$ & $-3,62(-2,99)$ & Kanada - Szwecja & $-2,66(-3,25)$ & $-2,37(-3,16)$ \\
\hline Australia - USA & $-3,64(-2,92)$ & $-4,25(-3,17)$ & Kanada - UK & $-1,65(-2,86)$ & $-2,05(-2,84)$ \\
\hline Australia - Włochy & $-1,45(-2,86)$ & $-1,06(-2,91)$ & Kanada - USA & $-1,90(-2,95)$ & $-1,60(-2,96)$ \\
\hline Francja - Japonia & $-2,25(-2,95)$ & $-0,80(-3,13)$ & Kanada - Włochy & $-1,73(-3,56)$ & $-1,31(-3,19)$ \\
\hline Francja - Kanada & $-4,22(-3,32)$ & $-4,03(-3,25)$ & Szwecja - UK & $-1,75(-2,82)$ & $-2,68(-2,84)$ \\
\hline Francja - Szwecja & $-2,85(-3,17)$ & $-2,73(-3,39)$ & Szwecja - USA & $-2,25(-2,91)$ & $-3,11(-2,91)$ \\
\hline Francja - UK & $-1,71(-3,02)$ & $-2,09(-3,26)$ & Szwecja - Włochy & $-2,11(-3,43)$ & $-0,41(-3,89)$ \\
\hline Francja - USA & $-4,33(-2,76)$ & $-5,21(-2,59)$ & UK - USA & $-2,88(-2,92)$ & $-4,47(-2,97)$ \\
\hline Francja - Włochy & $-2,42(-3,68)$ & $-2,60(-3,97)$ & UK - Włochy & $-1,21(-3,87)$ & $-0,06(-4,22)$ \\
\hline Japonia - Kanada & $-1,88(-2,96)$ & $-2,11(-3,27)$ & USA - Włochy & $-1,24(-3,58)$ & $-0,92(-3,92)$ \\
\hline
\end{tabular}

Tabela 5. Wyniki testów „inf” kointegracji stochastycznej

\begin{tabular}{|c|c|c|c|c|c|}
\hline Kraje & $\begin{array}{c}\text { LSTR } \\
\text { (boot. cv przy } \\
\alpha=10 \%)\end{array}$ & $\begin{array}{l}\text { ESTR (boot. cv } \\
\text { przy } \alpha=10 \% \text { ) }\end{array}$ & Kraje & $\begin{array}{c}\text { LSTR } \\
\text { (boot. cv, przy } \\
\alpha=10 \% \text { ) }\end{array}$ & $\begin{array}{c}\text { ESTR } \\
\text { (boot. cv przy } \\
\alpha=10 \% \text { ) }\end{array}$ \\
\hline Australia - Francja & $-3,30(-3,72)$ & $-3,71(-3,68)$ & Japonia - Szwecja & $-2,40(-4,36)$ & $-1,29(-3,92)$ \\
\hline Australia - Japonia & $-3,25(-3,89)$ & $-3,63(-3,99)$ & Japonia-UK & $-1,77(-3,29)$ & $-2,24(-3,79)$ \\
\hline Australia - Kanada & $-2,77(-3,53)$ & $-2,71(3,59)$ & Japonia - USA & $-2,26(-2,98)$ & $-3,48(-2,66)$ \\
\hline Australia - Szwecja & $-3,35(-3,58)$ & $-4,22(-3,74)$ & Japonia - Włochy & $-5,60(-3,19)$ & $-7,13(-3,31)$ \\
\hline Australia - UK & $-2,96(-3,48)$ & $-3,14(-3,75)$ & Kanada - Szwecja & $-2,45(-3,67)$ & $-2,36(-3,59)$ \\
\hline Australia - USA & $-3,00(-3,62)$ & $-2,96(-3,69)$ & Kanada-UK & $-1,36(-3,49)$ & $-1,83(-3,35)$ \\
\hline Australia - Włochy & $-3,27(-3,91)$ & $-3,62(3,77)$ & Kanada - USA & $-2,36(-3,09)$ & $-2,31(-3,06)$ \\
\hline Francja-Japonia & $-4,03(-3,29)$ & $-4,67(-3,480)$ & Kanada - Włochy & $-2,65(-3,86)$ & $-2,49(-3,73)$ \\
\hline Francja - Kanada & $-4,32(-3,52)$ & $-4,00(-3,77)$ & Szwecja-UK & $-1,73(-3,00)$ & $-2,68(-3,10)$ \\
\hline Francja-Szwecja & $-2,98(-4,04)$ & $-2,94(-4,04)$ & Szwecja - USA & $-2,39(-3,22)$ & $-3,28(-3,27)$ \\
\hline Francja-UK & $-2,39(-3,39)$ & $-3,03(-3,62)$ & Szwecja - Włochy & $-1,82(-4,05)$ & $-2,25(-4,33)$ \\
\hline Francja - USA & $-4,33(-2,88)$ & $-5,25(-2,91)$ & UK - USA & $-3,40(-3,62)$ & $-3,47(-3,43)$ \\
\hline Francja - Włochy & $-3,74(-4,52)$ & $-3,68(-4,24)$ & UK - Włochy & $-4,45(-4,70)$ & $-4,41(-4,62)$ \\
\hline Japonia - Kanada & $-2,53(-3,34)$ & $-2,76(-3,45)$ & USA - Włochy & $-4,28(-3,57)$ & $-4,14(3,52)$ \\
\hline
\end{tabular}


Tabele 2. i 3. podsumowują wyniki testów $F$ kointegracji STR. Dodatkowo zawarto w nich wyniki testu $t_{N E G}$ kointegracji ESTR, autorstwa Kapetaniosa, Shina i Snella (2006). Wnioskowanie przeprowadzono na podstawie symulowanych małopróbkowych wartości krytycznych. Wyniki zawarte w tabelach sugerują występowanie aż 8 przypadków konwergencji deterministycznej i 9 stochastycznej. Ponadto wnioskowanie w przypadkach, które wskazywała już procedura Engle'a -Grangera, jest obecnie znacznie silniejsze. Wśród bardzo silnych zależności deterministycznych należy wskazać związki między Francją i Kanadą oraz Australią i USA. W wersji stochastycznej występują natomiast np. zależności między Włochami a państwami takimi jak USA, UK czy Japonia. Wydaje się, że w analizowanych procesach dostosowawczych występują oba rodzaje efektów nieliniowych, tj. można obserwować zarówno nieproporcjonalność (kointegracja ESTR), jak i niesymetryczność (kointegracja LSTR) prędkości dostosowania. Przykładem, gdzie przeważa pierwszy z efektów, jest np. przypadek deterministycznej kointegracji ESTR dla par US-UK i Australia-UK, podczas gdy drugi efekt jest obserwowany np. dla zależności między Francją i Japonią, gdzie stwierdza się występowanie stochastycznej kointegracji LSTR, czy Francją i Kanadą, gdzie występuje deterministyczna kointegracja LSTR. Wydaje się jednak (na co wskazują przede wszystkim wyniki testu $t_{N E G}$ ), iż kointegracja ESTR, a więc dostosowanie nieproporcjonalne, pojawia się częściej.

W tabelach 4. i 5. zamieszczono podsumowanie wyników testów ,inf” kointegracji STR, które przeprowadzono w wersji bootstrap przy 200 replikacjach bootstrapowych i definicjach zbiorów dopuszczalnych wartości parametrów funkcji przejścia podanych w punkcie 3 . Zastosowano schemat generowania prób bootstrap bez restrykcji (tj. bootstrap oparty na resztach) oraz metodę nakładających się bloków o długości ustalonej arbitralnie jako 10. Wyniki zawarte w tabelach wskazują na występowanie 7 przypadków kointegracji deterministycznej i tylko 5 stochastycznej. Choć badania dotyczące mocy testów ,inf” wskazują, iż testy te mają zwykle wyższą moc niż testy $F$ i $t$ dla prób długości 100 i więcej obserwacji ${ }^{12}$, w przypadku próby małej (59 obserwacji) bootstrapowe warianty tych testów dostarczają gorszych wyników niż małopróbkowe wnioskowanie z wykorzystaniem statystyk $F$ i $t$. Generalnie testy ,inf” potwierdzają wyniki otrzymane wcześniej i - podobnie jak testy $F$ i $t$ - wskazują na częstsze występowanie dostosowania nieproporcjonalnego.

12 Patrz Bruzda (2007). 


\section{PODSUMOWANIE}

Osłabienie założenia o liniowości w analizie kointegracji pozwoliło wskazać znacznie więcej przypadków kointegracji deterministycznej i stochastycznej pomiędzy parami logarytmów PKB per capita i, tym samym, wzmocniło wnioskowanie na temat konwergencji gospodarczej. Procesy dostosowawcze do badanych zależności długookresowych charakteryzują się zarówno nieproporcjonalnością (szybszą prędkością dochodzenia do położenia równowagi dla dużych odchyleń od zależności długookresowej), jak i asymetrią (różną prędkością dostosowania dla dodatnich i ujemnych odchyleń), ale pierwszy z tych efektów zdaje się przeważać.

Wśród badanych 28 par gospodarek stwierdzono przypadki zarówno konwergencji deterministycznej (8), jak i stochastycznej (9). Wynik ten wskazuje z jednej strony występowanie stałych relacji między poziomami dochodu na głowę w takich państwach, jak: Australia, Francja, UK i USA, gdzie obserwuje się kointegrację parami i można mówić o swoistym klubie konwergencji deterministycznej. Z drugiej zaś pokazuje, że są kraje (Japonia, Włochy, Szwecja), w których poziom dochodu per capita jest stochastycznie skointegrowany z poziomem dochodu gospodarek o ustabilizowanych zależnościach długookresowych, co zdaje się wskazywać na proces zbiegania tych krajów do wspomnianej grupy państw o najbardziej ustabilizowanych powiązaniach dochodu per capita. Wynik ten stoi w zgodzie z ekonometrycznymi implikacjami neoklasycznego modelu wzrostu Solowa-Swana.

\section{LITERATURA}

Attfield C. L. F. (2003), Structural Breaks and Convergence in Output Growth in the EU, „Discussion Paper” 03/544, University of Bristol.

Barro R., Sala-i-Martin X. (1992), Convergence, „Journal of Political Economy”, vol. 100, 223-251.

Bernard A. B., Durlauf S. N. (1995), Convergence in International Output, „Journal of Applied Econometrics", vol. 10, 97-108.

Bernard A. B., Durlauf S. N. (1996), Interpreting Tests of the Convergence Hypothesis, „Journal of Econometrics”, vol. 71, 161-173.

Boyle G. E., McCarthy T. G. (1997), A Simple Measure of $\beta$-Convergence, „Oxford Bulletin of Economics and Statistics", vol. 59, 257-264.

Bruzda J. (2007), Procesy nieliniowe i zależności dlugookresowe w ekonomii. Analiza kointegracji nieliniowej, Wydawnictwo UMK, Torun. 
Christopoulos D. K., León-Ledesma M. A. (2007), International Output Convergence, Breaks, and Asymmetric Adjustment, INFER Workshop „Integration an Globalization: Challenges for Developed and Developing Countries", University of Coimbra, 29-30 czerwca 2007, Coimbra, Portugalia.

Ciołek D. (2003), Badanie konwergencji krajów Europy Środkowo-Wschodniej z wykorzystaniem danych panelowych, „Dynamiczne Modele Ekonometryczne”, vol. 8, $329-342$.

Furceri D. (2005), $\beta$ and $\sigma$-Convergence: A Mathematical Relation of Causality, „Economics Letters”, vol. 89, 212-215.

Islam N. (2003), What Have We Learnt from the Convergence Debate?, „Journal of Economic Surveys", vol. 17, 309-362.

Kapetanios, G., Shin, Y., Snell, A. (2006), Testing for Cointegration in Nonlinear Smooth Transition Error Correction Models, „Econometric Theory”, vol. 22, 279-303.

Li Q., Pappel D. (1999), Convergence of International Output. Time Series Evidence for 16 OECD Countries, „International Review of Economics and Finance”, vol. 8 , 267-280.

Maddison A. (2008), Statistics on World Population, GDP and Per Capita GDP, 1-2006 $A D$, http://www.ggdc.net/maddison.

Malaga K. (2004), Konwergencja gospodarcza w krajach OECD w świetle zagregowanych modeli wzrostu, Wydawnictwo AE w Poznaniu, Poznań.

Malaga K. (2007), Konwergencja gospodarcza. Próba syntezy, VIII Kongres Ekonomistów Polskich, 29-30 listopada 2007, Warszawa.

Mathunjwa J. S., Temple J. R. W. (2006), Convergence Behaviour in Exogenous Growth Models, „Discussion Paper” 06/590, University of Bristol.

Nowak W. (2005), Koncepcje konwergencji w teorii wzrostu gospodarczego, Konferencja „Nierówności społeczne a wzrost gospodarczy w obliczu regionalizacji i globalizacji”, Uniwersytet Rzeszowski, 22-23 września 2005, Rzeszów.

Olson M. (1982), The Rise and Decline of Nations, Yale University Press, New Haven.

Pesaran M. H. (2007), A Pair-Wise Approach to Testing for Output and Growth Convergence, „Journal of Econometrics”, vol. 138, 312-355.

Sala-i-Martin X. X. (1996a), The Classical Approach to Convergence Analysis, „Economic Journal", vol. 106, 1019-1036.

Sala-i-Martin X. X. (1996b), Regional Cohesion: Evidence and Theories of Regional Growth and Convergence, „European Economic Review”, vol. 40, 1325-1352.

Solow R. M. (1956), A Contribution to the Theory of Economic Growth, „Quarterly Journal of Economics", vol. 70, 65-94.

Swan T. V. (1956), Economic Growth and Capital Accumulation, „Economic Rekord”, vol. 32, 334-361.

Teräsvirta T. (1994), Specification, Estimation, and Evaluation of Smooth Transition Autoregressive Models, „Journal of the American Statistical Association”, vol. 89, 208-218. 


\title{
OUTPUT CONVERGENCE IN THE CHOSEN OECD COUNTRIES: THE NONLINEAR COINTEGRATION APPROACH
}

\begin{abstract}
A b s tract. The paper verifies the convergence hypothesis for eight OECD economies: Australia, Canada, France, Italy, Japan, Sweden, the United Kingdom and the United States, utilising the annual post-war data. The examination makes use of cointegration analysis that enables to verify the deterministic as well as stochastic convergence hypotheses. In the empirical analysis tests allowing for asymmetric and nonproportional speeds of adjustments to steady states are used. The tests are based on logistic and exponential smooth transition autoregressive models for equilibtium errors and are reffered to as the LSTR (logistic smooth transition) and ESTR (exponential smooth transition) cointegration tests, respectively. The relaxation of the linearity assumption in the cointegration analysis let us to single out more cointegrating relationships and strengthen the inference in favour of the convergence hypothesis. The adjustment processes to the examined long-term relationships seem to be characterised by both types of nonlinearity, i.e. asymmetry and nonproportionality. The results stay in accordance with econometric implications of the neoclassical Solow-Swan growth model.
\end{abstract}

Keywords: $\beta$-convergence, nonlinear cointegration, STAR models, neoclassical growth models. 